\title{
RESULTS OF TREATMENT OF INFEGTIONS OF THE HAND
}

\author{
J. C. Scott and B. V. Jones, Oxford, England
}

From the Accidint Service, United Oxford Hospitals

A preliminary report on a method of treatment of infections of the hand was published from this Unit (Loudon, Mineiro and Scott, 1948). It was emphasised at that time that this was a small series of cases treated by the authors and that a report on a larger series would be published in due course. The essentials of the method were excision of all devitalised tissues and suture of the wound, plaster protection and immobilisation, parenteral penicillin and infrequent dressings. It was not suggested that this method was the answer to all types and stages of hand infection. It was pointed out that it was possible to obtain primary healing in a high proportion of hand infections if certain conditions were carefully observed and that this was a new observation in relation to these infections which was worthy of further consideration.

\section{CLINICAL MATERIAL}

We have now reviewed the records of 1,211 patients treated for hand infections from July 1948 to April 1951 ; of these, 145 resolved with conservative treatment and 1,066 required operation. For purposes of analysis it has been necessary to exclude 195 cases because the notes were inadequate in respect of treatment or follow up. The patients included in this series were dealt with throughout by all the members of the staff of the Accident Service and the routine followed was the same as for all other patients. They were seen and dealt with for the most part by the house surgeons to the Accident Service under the supervision of the senior residents and the consultant staff. The interest of the residents in this subject and their proficiency in dealing with it was stimulated in every possible way and it was impressed upon them that advice was available and should be sought whenever they were in doubt. As well as the general daily clinic a special septic hand clinic was held weekly to see any patient whose progress was not satisfactory. In about two-thirds, excision and suture were carried out; in the remainder other methods were considered more suitable by the person doing the operation. It is therefore not possible to compare the results obtained by different methods.

Our chief interest is in those in which primary healing was obtained; and in those in which it was not, the reasons for the failures and any complications which arose. The criterion adopted of success or failure is whether or not primary healing was obtained. An arbitrary figure for primary healing has been taken as seventeen days or less. This was done chiefly for two reasons. In no case in which there was any breakdown of the wound and discharge of pus did healing take place within seventeen days. With infrequent dressings there was, in a proportion of cases, a tendency to remove the sutures at the tenth day, apply a dry dressing, advise activity and see the patient again in a week. When there was any doubt about the completeness of healing on the tenth day, the case would be included as having healed (per primam) in seventeen days.

The healing time must be related as closely as possible to the severity of infection. Because of different descriptive methods and terminology it is difficult to describe " severity" in words which will be interpreted in the same way by all readers. The " degree" method, previously described, has obvious faults but we use it here because we believe it to be as reliable as any other method. First degree means no pus found; second-pus localised and confined to one space; third-pus extended from original site into other tissues; and fourthdischarging sinus. 
Table I shows the proportion of the different types of infection which make up the total. In all groups except paronychia the cases have been divided into those which healed per primam and those which did not, and the relevant figures with regard to healing time and degree of infection have been analysed.

TABLE I

TYPE OF INFECTION

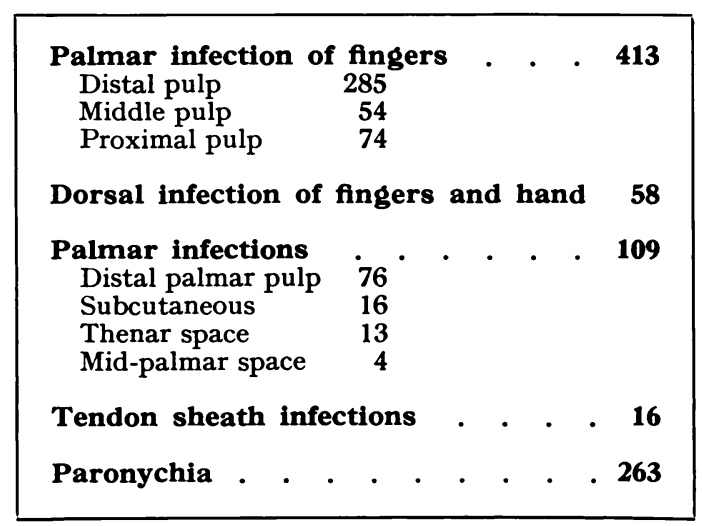

\section{RESULTS}

Palmar infections of fingers (Table II) - If the palmar infections of the fingers are grouped together we find that, of 347 treated by excision and suture, 56 per cent healed by first intention in an average of just over eleven days, and that $\mathbf{4 3}$ per cent failed to do so and took an average of thirty-three days to heal: there was bone involvement in twenty cases, in five of which sequestrum formation occurred.

TABLE II

Palmar Infections of the Fingers

\begin{tabular}{|c|c|c|c|c|c|}
\hline \multirow{2}{*}{ Site of infection } & \multirow{2}{*}{$\begin{array}{l}\text { Number } \\
\text { of cases }\end{array}$} & \multicolumn{2}{|c|}{ Primary healing } & \multicolumn{2}{|c|}{ No primary healing } \\
\hline & & Number & Per cent & Number & Per cent \\
\hline $\begin{array}{l}\text { Distal pulp } \\
\text { Middle pulp } \\
\text { Proximal pulp }\end{array}$ & $\begin{array}{r}226 \\
50 \\
71\end{array}$ & $\begin{array}{r}133 \\
24 \\
39\end{array}$ & & $\begin{array}{l}93 \\
26 \\
32\end{array}$ & \\
\hline \multirow[t]{2}{*}{ Total } & 347 & 196 & $56 \cdot 5$ & 151 & $43 \cdot 5$ \\
\hline & & \multicolumn{2}{|c|}{$\begin{array}{l}\text { Average healing } \\
\text { time, } 11 \cdot 4 \text { days }\end{array}$} & \multicolumn{2}{|c|}{$\begin{array}{c}\text { Average healing } \\
\text { time, } 34 \cdot 3 \text { days }\end{array}$} \\
\hline \multicolumn{2}{|c|}{ Degree of infection } & \multicolumn{2}{|c|}{ Primary healing } & \multicolumn{2}{|c|}{ No primary healing } \\
\hline $\begin{array}{l}\text { First degree } \\
\text { Second degree } \\
\text { Third degree. } \\
\text { Fourth degree }\end{array}$ & $\dot{.}$ & \multicolumn{2}{|c|}{$\begin{array}{l}9 \cdot 2 \text { per cent } \\
51 \cdot 1 \text { per cent } \\
20 \cdot 4 \text { per cent } \\
17 \cdot 3 \text { per cent }\end{array}$} & \multicolumn{2}{|c|}{$\begin{array}{l}23.8 \text { per cent } \\
26.5 \text { per cent } \\
49.7 \text { per cent }\end{array}$} \\
\hline
\end{tabular}

In these 347 patients there were 362 operations and two dressings under anaesthesia in children. There were second operations in $4 \cdot 3$ per cent-of the fifteen second operations eight were skin grafts and seven were needed to improve drainage or remove a sequestrum. Two per cent of the patients required a second operation before effective drainage was achieved. There were three instances of damage to the neurovascular bundle, two definite and one doubtful. Twenty-six patients were admitted to hospital. 
Dorsal infections of fingers and hand (Table III) - There were fifty-eight dorsal infections of fingers and hands, and forty-seven of these were treated by excision and suture. Fifty-one per cent healed by first intention, and second operations were required in five patients, four of them being for skin grafts. There were no other complications. Six patients were admitted to hospital.

TABLE III

Dorsal Infections of Fingers and Hand

\begin{tabular}{|c|c|c|c|}
\hline \multirow{2}{*}{ Number of cases } & \multicolumn{2}{|c|}{ Primary healing } & No primary healing \\
\hline & Number & per cent & Number Per cent \\
\hline \multirow[t]{2}{*}{47} & 24 & 51 & 23 \\
\hline & \multicolumn{2}{|c|}{$\begin{array}{l}\text { Average healing } \\
\text { time, } 13.5 \text { days }\end{array}$} & $\begin{array}{l}\text { Average healing } \\
\text { time, } 29.9 \text { days }\end{array}$ \\
\hline Degree of infection & \multicolumn{2}{|c|}{$\begin{array}{l}\text { Primary healing } \\
\text { (cases) }\end{array}$} & $\begin{array}{l}\text { No primary healing } \\
\text { (cases) }\end{array}$ \\
\hline $\begin{array}{l}\text { First degree } \\
\text { Second degree } \\
\text { Third degree } \\
\text { Fourth degree }\end{array}$ & \multicolumn{2}{|c|}{$\begin{array}{l}1 \\
9 \\
7 \\
7\end{array}$} & $\begin{array}{r}\overline{2} \\
11 \\
10\end{array}$ \\
\hline
\end{tabular}

Infections of palm (Table IV)-There were 119 infections of the palm, and ninety-six of them were treated by excision and suture. Fifty-two per cent of these healed by first intention. A second operation was required in four patients, but not because of failure to produce effective drainage. It is interesting that only about one-sixth of these infections were fourth degree as compared with one-third in the case of finger pulp infections. This

TABLE IV

Infections of the PaLm

\begin{tabular}{|c|c|c|c|c|c|}
\hline \multirow{2}{*}{ Site of infection } & \multirow{2}{*}{$\begin{array}{l}\text { Number } \\
\text { of cases }\end{array}$} & \multicolumn{2}{|c|}{ Primary healing } & \multicolumn{2}{|c|}{ No primary healing } \\
\hline & & Number & Per cent & Number & Per cent \\
\hline $\begin{array}{l}\text { Distal palmar pulp } \\
\text { Subcutaneous } \\
\text { Thenar space } \\
\text { Mid-palmar space. } \\
\text { Hypothenar space }\end{array}$ & $\begin{array}{r}70 \\
13 \\
10 \\
3 \\
-\end{array}$ & $\begin{array}{r}37 \\
6 \\
5 \\
2 \\
-\end{array}$ & & $\begin{array}{r}33 \\
7 \\
5 \\
1 \\
-\end{array}$ & \\
\hline \multirow[t]{2}{*}{ Total } & 96 & 50 & 52 & 46 & 48 \\
\hline & & \multicolumn{2}{|c|}{$\begin{array}{l}\text { Average healing } \\
\text { time, } 11.9 \text { days }\end{array}$} & \multicolumn{2}{|c|}{$\begin{array}{l}\text { Average healing } \\
\text { time, } 31 \cdot 1 \text { days }\end{array}$} \\
\hline \multicolumn{2}{|c|}{ Degree of infection } & \multicolumn{2}{|c|}{$\begin{array}{l}\text { Primary healing } \\
\text { (cases) }\end{array}$} & \multicolumn{2}{|c|}{$\begin{array}{c}\text { No primary healing } \\
\text { (cases) }\end{array}$} \\
\hline $\begin{array}{l}\text { First degree } \\
\text { Second degree } \\
\text { Third degree. } \\
\text { Fourth degree }\end{array}$ & i & $\begin{array}{l}2 \\
1\end{array}$ & 9 & & $\begin{array}{l}5 \\
5\end{array}$ \\
\hline
\end{tabular}

may be because the thick palmar skin does not break down to form a sinus but rather forces the infection to spread. It was found that when long transverse incisions were used there was a tendency for them to open up if mobilised early. Damage occurred to three neurovascular bundles. Twenty-seven patients were admitted to hospital.

vol. $34 \mathrm{~B}$, No. 4, NOVEMBER 1952 
Tendon sheath infections-There were sixteen patients with tendon sheath infection, ten being secondary to other finger infections (five of which had discharging sinuses) and five due to wounds or bites. One was a primary sheath infection. Six healed per primam in an average of $13 \cdot 6$ days and in five of them good function resulted. Of the other ten, eight healed in an average time of $\mathbf{3 6 . 5}$ days; three of these regained good function, in two it was fair, in two poor and in one unknown. Two fingers were amputated, one after healing and the other (with a multiple space infection extending to the tendon sheath) on the eighteenth day. In the whole series there were three other amputations - two for stiff fingers after multiple pulp space infections and one immediate amputation of the fifth finger for a very late and extensive infection. It was noted in a considerable proportion of third and fourth degree infections that the pus was tracking along the neurovascular bundle.

TABLE V

PARONYCHIA

\begin{tabular}{|ccccc|}
\hline Treatment & & $\begin{array}{c}\text { Number } \\
\text { of cases }\end{array}$ & $\begin{array}{c}\text { Average healing } \\
\text { time }\end{array}$ \\
\hline Usual incisions. & $\cdot$ & & 138 & $13 \cdot 3$ days \\
Usual incisions plus suture & & 93 & $13 \cdot 1$ days \\
Removal of nail only & & 32 & $16 \cdot 6$ days \\
\hline Total & $\cdot$ & $\cdot$ & 263 & \\
\hline
\end{tabular}

Paronychia (Table V)-The only way in which our method of treatment of paronychia differs from those usually adopted is that an attempt is made to excise devitalised tissue and that when this is possible the incisions are sutured. This suture has some value in preventing retraction of scars at the base of the nail and the excision in assisting the growth of the new nail by providing early elimination of infected material. The results are shown in Table V.

\section{CAUSES OF FAILURE}

These can be classified into two groups: those in which there was trouble with the skin, and those in which excision was inadequate or infection led to further death of tissue.

Skin troubles arise from two sources-the first and most frequent is the presence before operation of dead skin with or without a sinus. The procedure has been to excise the sinus, thereby placing some tension on this part of the wound leading to separation of the edges and a small granulating area. The inclusion of the sinus in the incision sometimes required modification of accepted incisions. These modified incisions frequently produced trouble. The estimation of death of skin around a sinus is not always easy and on occasion it was evident that dead skin had been sutured.

The second cause of skin trouble was from the incision leading to death of some part of the skin flap. This varied from a little moisture at the edge to the death of the whole flap. The severe degrees were uncommon and associated in almost all instances with serious infections where the viability of skin was in doubt. In some cases a right-angle incision was used instead of a curve and led to an area of necrosis at the corner. One complication which was associated with these difficulties was haematoma formation. It was infrequent and usually associated with some break in the technique such as changed site or shape of incision or variation of routine in relation to the tourniquet.

Complete excision of non-viable tissue is an absolute essential to uniformly good results and is the aspect of the procedure which requires most thought and care. There were a number 
of instances in which the operator was satisfied that he had carried out an adequate excision and his error was due to the absence of localisation. There were others in which suture was mistakenly carried out after what was known to be inadequate excision.

These are briefly the reasons for the failures and it is difficult to generalise about the relative frequency and importance of the various causes. For example, of the 226 distal pulp space infections there were ninety-three which failed to heal per primam, and in the detailed analysis of these it was found that in more than half the delay in healing was due to the granulation of a sinus or a small part of the incision-in none of these was there retained infection or significant symptoms after the operation. In only thirteen was inadequate excision apparently the cause of the delay.

\section{DISCUSSION}

Our main purpose is to report results and no attempt is to be made to discuss all aspects of the problem or to comment on recent papers. It is proposed to mention only those items which seem to be of importance to this report.

One is the conflict of opinion on the relative importance of ischaemia from tension and the effect of the staphylococcus on the tissues. It seems likely that these factors are complementary in producing the sequence of events which leads to extensive tissue destruction. The only way the tissues have of resisting the proteolytic effect of the organisms is to increase the concentration of antibodies by increased blood flow. When the infection is controlled at the stage when some tissue has been destroyed and a localised abscess formed, the problem is still a relatively simple one. There is, unfortunately, a high proportion in which the resistance is inadequate and the process does not stop until extensive tissue destruction has taken place.

The cellulitis around the site of primary infection varies considerably and is sometimes a useful guide to the prognosis. An active reaction might well be expected to signify an early localisation. This sometimes follows, but more often it is an indication of the inability of the tissues to contain the infection and at this stage surgery should be delayed until it has been possible to see the effect of penicillin. The absence of a brisk cellulitis may engender a false sense of security, as there may be little or no reaction around an infection which is quietly and progressively destroying the whole of a pulp space.

In any particular case in which both factors-staphylococcal toxin and local tensionare operating, it is essential that both should be dealt with as quickly as possible. Once pus forms in any of the spaces in the hand there is no evidence to suggest that it resolves in any significant number of cases; it is therefore essential that it should be removed.

In distal pulp infections the diagnosis and treatment of osteitis is a problem which receives much attention. Bone infection was present in a very small proportion in this series. This is probably due in part to the stage at which they were seen and to the treatment given, but even more to the fact that osteitis was based on a clinical rather than radiological diagnosis. In any severe pulp space infection radiographs will at some stage show changes in the phalanx which may be diagnosed as osteitis. The most common change is a diffuse osteoporosis from persistent hyperaemia, similar to the changes seen in the bones around the knee joint in a chronic synovial infection. If the hyperaemia and/or the treatment is sufficient to deal with the infection no further changes occur. If it is not, then the bone may become infected. It is sometimes surprising to see extensive bone changes shown in the radiograph return to normal without any sequestration.

The difference of opinion with regard to the value of antibiotics in the treatment of hand infections raises points of interest and importance. Culture of the organisms was done in a large proportion of the cases and the results were similar to those in most other series. It is interesting to note that of eighty-two staphylococcus aureus infections in which penicillin resistance was tested not one resistant strain was found.

vol. 34 B, No. 4, NOVEMBER 1952 
Little is said about the value or otherwise of poulticing, the form of early treatment accepted by all laymen and many general practitioners. It probably does a good deal of harm in certain types and stages of infection.

In the early stages, before pus is present, every infection has been given the opportunity and assistance to subside and this has been done with immobilisation and adequate penicillin for five days or more. Even when pus was present, with a good deal of cellulitis around the site, a period of up to twenty-four hours' immobilisation and penicillin was found to be of value before surgical intervention.

One great difficulty in the early stage is to be certain whether or not pus is present. This problem is one with which we would like to be confronted more frequently-in all too many of the fingers there is no room for doubt. That it is not frequent enough is borne out by the fact that in only 4 per cent of the patients operated on was no pus found.

Technique-A brief review of some aspects of the technique used is perhaps justified. The anaesthetic-We are more firmly of the opinion that general anaesthesia is the method of choice for any deep finger or hand infection and that ring block for fingers should be condemned. More remote regional anaesthesia has a place under certain conditions. The incision-The incisions described in the previous paper were worked out with great care and when they have been adhered to there has been little trouble. For various reasons it is not always possible to adhere to them and in the attempt to excise the lesion adequately incisions have been turned and extended, with consequent trouble with flaps in some cases and delayed healing. This is of sufficient importance to suggest that the procedure should be abandoned when modification of incision becomes necessary. The excision-The technical difficulties of excision have already been mentioned. It is difficult to get people to distinguish between "dead" and "infected" tissues - not surprising perhaps when we remember that this difficulty led to so much of the disagreement about wound excision during the war. Suture-The three essentials here are adequate excision, viable skin flaps and no damage to main blood vessels. When there is any doubt about the efficiency of the excision the wound should be left open and skin of doubtful viability should not be sutured. When there is no retained infection sutures should always be left in for ten days, and longer if desired, even after mobilisation is started. Immobilisation must be effective to be of any value, but on no account must it be tight.

In the series of cases analysed above there has been no attempt to make a comparison of the results with any parallel series treated by other methods. The series comprised about two-thirds of all septic hands operated on in the period under review; the remaining cases were for the most part minor ones in which excision and suture were clearly unnecessary. It will be noticed that the incidence of paronychia is lower and the incidence of tendon sheath and palmar space infections much higher than in most recently published series.

There is no simple or single answer to the treatment of hand infections. In theory there is no doubt that excision and suture is the ideal method and we must therfore try carefully to determine those cases most suited to this method. In practice we were aware that difficulties existed and this review has made it possible to assess them.

\section{INDIGATIONS AND CONTRA-INDIGATIONS FOR EXGISION AND SUTURE}

This method is designed to give the patient the best possible treatment when adequate facilities are available. It is in the more severe and serious infections that it finds its greatest application, and as a matter of principle the treatment of severe hand infections ought not to be undertaken without adequate facilities for careful and unhurried surgery. It is not a suitable technique for use in general practice.

Its chief advantages are the way in which severe infections can be controlled by it, the lack of post-operative pain and the fact that frequent dressings are not required. This saves 
the patient much time and discomfort, and incidentally cuts down work in the casualty department and reduces the amount of dressing materials used.

It should be used when there is a well localised infection-where pus can be removed, all dead tissues excised and healthy skin sutured without tension. In tendon sheath infections its use is clearly indicated, for these give unsatisfactory results when dealt with by simple drainage methods. It can deal with the ramifications of multilocular abscesses, such as are found in the palm and distal palmar spaces, more effectively than any other method. It is a good way of eradicating small, deep-seated abscesses such as are found in the distal pulp space.

It should be avoided when the infection is poorly localised and the dividing line between dead and living tissue poorly demarcated, and when the infection is so extensive that complete excision is not practical. Those cases in which there is a sinus that cannot conveniently be included in an orthodox incision or in which the viability of the skin about the sinus is in doubt are better treated by some form of simple "unroofing" procedure. This is because, by the time a sinus has formed, multilocular abscesses have usually coalesced into a single collection of pus which is easily drained. Nevertheless excision, with or without suture, can often play a useful part in the late treatment of distal pulp infections with sequestra and sinuses. In superficial infections-including apical, dorsal and palmar-simple drainage will lead to equally rapid healing.

Apart from its therapeutic value, the exposure provided by this technique has taught us a good deal about the detailed pathology of the infected finger. It has shown us that diffuse cellulitis is not limited to streptococcal infections, and has demonstrated how an infection tracks from one pulp space to another and thence to the palm along the neurovascular bundles, and how it spreads along the fibres of the palmar fascia in distal web space infections to involve one space after another. We have seen how often the clinical diagnosis of tendon sheath infection is wrong, and also how often an unsuspected sheath infection may be present.

\section{SUMMARY}

1. A series of 1,211 cases of infection of the hand and fingers is reviewed. Of the 1,066 which required operation about two-thirds were treated by excision and suture, and the results in these cases are analysed.

2. The criterion of success was per primam healing in seventeen days or less, and $\mathbf{5 4}$ per cent of the cases treated by this method (excluding paronychiae) fulfilled this criterion.

3. The causes of failure are discussed.

4. It is concluded that excision and suture is the method of choice in well localised infections, but that it should be avoided in diffuse infections and in some cases with sinuses. Its use is unnecessary in trivial infections.

\section{REFERENCE}

Loudon, J. B., Miniero, J. D., and Scott, J. C. (1948): Infections of the Hand. Journal of Bone and Joint Surgery, 30-B, 409. 